\title{
Keterkaitan kebiasaan manusia terhadap kondisi gigi
}

\section{Daily habit and the condition of dentition}

\author{
Widya Ayu Permatasari ${ }^{1}$ \& Myrtati D. Artaria $^{2}$ \\ 1) Program Studi Antropologi, FIB, Universitas Brawijaya, Malang \\ Jalan Veteran Malang, Kota Malang, Jawa Timur 65145, Indonesia, Phone: +62 341575875 \\ 2) Departemen Antropologi, FISIP, Universitas Airlangga, Surabaya \\ E-mail: widyayu@live.com
}

\begin{abstract}
Many daily habits relates to the condition of dentition. Therefore it is interesting to study in the coastal society that has unique daily habit and food, that may affect the condition of their dentition. This research used ethnography method. This method has two way to get information, (1) interview and (2) observation. Researcher lived in Dusun Tawang Kulon, District Sidomulyo, sub Ngadirojo, Pacitan for 1 month. Researcher interviewed 19 people age 30-90 years old and experienced tooth illnesses condition. Qualitative data analysis use data collection, categorization of the data obtained, resulting domain, interpretation and conclusions. The result of this research shows that society in Tawang Kulon, District Sidomulyo, sub Ngadirojo practice several types of behavior that relate to tooth condition. That three types human behavior are (1) dietary behavior, for example is how to make gaplek flour and food flavour, (2) incidental cultural behavior, for example using tooth-picks (3) intentional cultural modification, for example nginang-bethel nut chewing, and pangur-teeth-filing. In term of oral health, prevention is not very common. As long as the society did not feel any pain, they did not seek for medication. When there is tooth-ache, first, they did nothing expecting the pain will go away by itself. Second they will try heal using traditional medication or over-the-counter medication such as pain killer. If the pain persists, then, they visit the dentist or dental nurse.
\end{abstract}

Keywords: human behavior, habit, tooth condition, healing decision, ethnography

\begin{abstract}
Abstrak
Banyak kebiasaan manusia sehari-hari berpengaruh terhadap giginya. Karenanya menarik untuk diteliti, bagaimana manusia di pesisir yang mempunyai kebiasaan dan makanan yang khas, yang kemungkinan berdampak pada giginya. Penelitian ini menggunakan pendekatan etnografi dengan menggunakan dua cara pengambilan data yaitu wawancara dan observasi. Penelitian dilakukan dengan cara menginap selama kurang lebih 1 bulan di Dusun Tawang Kulon, Desa Sidomulyo, Kecamatan Ngadirojo, Kabupaten Pacitan. Wawancara dilakukan kepada 19 informan dengan kisaran umur 30-90 tahun. Analisis data kualitatif yang dilakukan adalah pengumpulan data, pengkategorisasian data-data yang diperoleh, menghasilkan domain, diinterpretasikan dan diambil simpulannya. Hasil penelitian menunjukkan bahwa masyarakat Dusun Tawang Kulon, Desa Sidomulyo, Kec Ngadirojo hanya terdapat tiga tingkah laku manusia yang berhubungan dengan kondisi gigi. Ketiga tingkah laku tersebut yaitu (1) berhubungan dengan makanan, dicontohkan dalam pembuatan tepung gaplek dan bumbubumbu masakan (2) berhubungan dengan modifikasi yang tidak disengaja, dicontohkan dalam kebiasaan penggunaan tusuk gigi (3) berhubungan dengan modifikasi yang disengaja, dicontohkan dalam kebiasaan nginang dan pangur gigi bagi perempuan. Pengambilan keputusan dalam pengobatan gigi yang sakit adalah masyarakat melakukan pembiaran terlebih dahulu, kemudian akan melakukan pengobatan sendiri jika rasa sakit tidak kunjung hilang. Jika rasa sakit kembali datang dan lebih mengganggu, mereka akan melakukan kunjungan ke dokter gigi atau perawat gigi.
\end{abstract}

Kata kunci: tingkah laku manusia, kebiasaan, kondisi gigi, pengambilan keputusan pengobatan, etnografi

\section{Pendahuluan}

Gigi merupakan salah satu dari sekian banyak bagian dalam tubuh manusia. Setiap hari banyak tingkah laku yang dilakukan menggunakan gigi. Tingkah laku-tingkah laku yang telah menjadi kebiasaan berangsur-angsur akan membentuk ciri-ciri khusus pada gigi. Bahkan tak jarang tingkah laku-tingkah laku tersebut memiliki pengaruh terhadap kesehatan gigi. 
Terdapat reaksi yang terjadi pada gigi akibat modifikasi terhadap gigi atau karena aktifitas yang diterima oleh gigi. G. Richard Scott membagi tingkah laku manusia yang memiliki hubungan dengan kondisi gigi ke dalam 4 bagian, yaitu tingkah laku manusia yang berhubungan dengan makanan, tingkah laku manusia yang berhubungan dengan peralatan, tingkah laku manusia yang berhubungan dengan modifikasi budaya yang tidak disengaja, serta tingkah laku manusia yang berhubungan dengan modifikasi budaya yang disengaja (Scott 1997).

Tingkah laku manusia yang berhubungan dengan makanan memiliki kaitan terhadap gambaran kondisi gigi. Hal ini dikarenakan gigi sebagai alat mengunyah, merobek, memisahkkan dan menghaluskan makanan. Smith (dalam Alt \& Pichler 1998:392-393) berpendapat bahwa variasi makanan, cara mempersiapkan makanan, serta komponen-komponen yang kemungkinan dapat masuk dalam makanan sangat berpengaruh terhadap kondisi gigi. Kondisi gigi yang muncul adalah abrasi dan pola-pola khas yang ditinggalkan pada permukaan occlusal.

Prossinger dan Willms (1998:318) dalam penelitiannya mengenai sejarah makanan dan nutrisi di Eropa pada masa prasejarah memperlihatkan hubungan yang kuat antara kondisi gigi manusia dan kebiasaan makan dalam sebuah populasi, khususnya munculnya caries pada gigi manusia. Prossinger dan Willms mencoba menjabarkan periode demi periode bagaimana manusia memperoleh makanan (baik hewan maupun tumbuhan), proses memasaknya serta bahan-bahan yang digunakan. Bahkan variasi tanaman di setiap lingkungan dapat menjadi penyebab kerusakan gigi. Beras tidak menyebabkan kerusakan gigi jika dibandingkan dengan jagung. Populasi di Amerika Utara yang bercocok tanam jagung memiliki frekuensi caries lebih besar dari mereka yang bercocok tanam padi (beras) (Larsen 2008:408).

Trikarjana (2005:1067-1072) juga melihat bagaimana kebiasaan masyarakat Pelembang dalam mengkonsumsi "Pempek" berpengaruh terhadap kondisi gigi. Komposisi "pempek" yang terbuat dari sagu dan kuah cukanya memberikan efek tidak baik terhadap gigi. Sagu yang bersifat lengket memudahkannya menempel pada gigi, sehingga sisa-sisa sagu yang terdapat pada gigi memberikan kesempatan bagi bakteri untuk menempel dan menggerogoti mahkota gigi. Cuka yang bersifat asam juga mempengaruhi proses demineralisasi (larutnya mineral enamel gigi akibat asam).

Kebiasaan tingkah laku menggunakan gigi sebagai alat tak hanya dilakukan pada masyarakat dahulu, namun juga pada masyarakat saat ini. Scott (1997:186) berpendapat bahwa gigi memiliki berbagai fungsi, bahkan sebagai alat yang unik karena dapat menjadi tangan ketiga.

Kurt W. Alt dan Sandra L. Pichler (1998:394) menyebutkan bahwa penggunaan gigi sebagai alat terdapat di populasi tertentu yang memiliki hubungan dengan pekerjaannya. Mereka menemukan tanda-tanda yang khas pada gigi di populasi yang berbeda seperti pada penjahit wanita (memutuskan benang), pembuat sepatu atau tukang kayu (menggigit paku), tukang daging (memutuskan senar), musisi alat tiup, pekerja kantoran (menggigit pensil) dan beberapa pemain sulap (menggigit peralatan sulap).

Tingkah laku memutuskan benang dengan menggunakan gigi juga menyebabkan terbentuknya lekukan-lekukan pada permukaan oklusal (permukaan kunyah) gigi depan (Artaria 2009:82). Bahkan pada populasi masyarakat berburu dan meramu, gigi juga digunakan dalam menghaluskan kulit Walrus atau anjing laut yang berguna sebagai alas kaki. Hal ini menyebabkan pola keausan pada gigi labial (gigi-gigi pada bagian depan) (Scott 1997:186). Pemain saxofon profesional melakukan latihan dengan kisaran waktu lebih dari 6 jam dalam sehari. Tingkah laku ini meninggalkan bekas pada gigi geligi. Gigi geligi akan mengalami cekungan pada bagian depan atas dan bawah akibat gigi menjepit ujung tiup saxofon. Perokok yang menggunakan pipa rokok juga memiliki cekungan pada gigi geligi. Hal ini disebabkan oleh intensitas tingkah laku merokok dengan pipa yang berlebihan (Koesbardiati 2014).

Tingkah laku manusia yang berhubungan dengan modifikasi budaya yang tidak disengaja juga mempengaruhi kondisi gigi. Scott memberikan beberapa contoh seperti penggunaan tusuk gigi atau tooth-picks. Kebiasaan penggunaan tusuk gigi ini meninggalkan bekas guratan-guratan atau alur di celah-celah mahkota gigi (Scott 1997:187). Tingkah laku lainnya adalah kebiasaan merokok dengan 
menggunakan pipa rokok. Kebiasaan ini menimbulkan bekas goresan-gorean berbentuk bulat telur di beberapa gigi (Scott 1997:187). Popoviciu (dalam Alt \& Pichler 1998:400) juga memberikan contoh pada populasi di area Mediterania yang memiliki tingkah laku sehari-hari memecahkan dan mengunyah bibit kering (bibit bunga matahari, labu dll).

Pada masyarakat Eskimo di awal abad 19 tingkah laku penggunaan labret menimbulkan guratan yang berkilat pada labial (gigi yang terlihat ketika tersenyum) atau buccal (gigi yang menunjuk ke arah pipi) di gigi anterior atau gigi posterior. Labret adalah aksesoris yang terbuat dari tulang, batu, gading atau kayu, yang dimasukkan melalui pipi dengan bentuk yang beragam (Scott 1997:187). Garve (dalam Alt \& Pichler 1998:402) juga memberikan contoh pada masyarakat Indian Brazil Amazon yang menggunakan boteru (semacam labret namun penggunaan di bibir bagian bawah). Boteru yang berukuran $15 \mathrm{~cm}$ panjangnya dan $4 \mathrm{~cm}$ diameternya disisipkan pada bibir bagian bawah. Penggunaan boteru tersebut menyebabkan tereksposnya akar pada dua hingga tiga gigi incisors pada rahang bawah.

Keberadaan gigi juga tak lepas dari adanya tingkah laku manusia yang berhubungan dengan modifikasi yang disengaja, baik masa sebelum modern hingga masa modern. Scott (1997:187) mengatakan bahwa manusia dapat memodifikasi penampilan mulut dan gigi dalam berbagai cara, seperti penggunaan labrets, tato, pewarna bibir, serta modifikasi gigi seri dan gigi taring (memutilasi). Mengikir gigi adalah salah satu dari kegiatan mutilasi gigi. Terdapat beberapa tempat dengan kegiatan mutilasi gigi sering dilakukan, yaitu Afrika, Amerika Tengah dan Amerika Selatan, Philipina dan Asia Tenggara (Gould 1984, Fastlicht 1976, Galang 1941 dalam Alt \& Pichler 1998:406). Di lain pihak modifikasi gigi juga terjadi dengan menanamkan emas, atau batu-batuan ke dalam gigi (Scott 1997:188).

Di Jepang banyak dijumpai modifikasi gigi dengan cara pewarnaan pada gigi. Bahkan di Asia Tenggara juga dijumpai modifikasi dengan cara mencabut gigi atau ablasi (Artaria 2009:80). Di Indonesia dijumpai tradisi modifikasi gigi pada penduduk Bali. Tradisi ini dilakukan dengan gambaran melakukan pengikiran atau pengasahan pada gigi. Penduduk Bali menyebutnya metatah atau mepandes (Geertz 1981:32). Terdapat beberapa alasan mengapa modifikasi-modifikasi tersebut dilakukan, yaitu sebagai ritus inisiasi, penanda status sosial bahkan sebagai kosmetik (Artaria 2009:81). Amalisa Iptika (2014:64-69) melakukan penelitian mengenai hubungan antara kepercayaan dan kebiasaan masyarakat Jawa dalam mengunyah sirih pinang dengan kesehatan gigi. Hasil penelitian ini diketahui bahwa masyarakat yang memiliki kebiasaan mengunyah sirih pinang kesehatan giginya mengalami gangguan. Gangguan yang diderita antara lain gigi tanggal, caries, dan warna gigi yang berubah.

Keunikan dari gigi serta kaitannya dengan tingkah laku-tingkah laku yang mempengaruhinya memberikan tema menarik bagi peneliti untuk meneliti tingkah laku-tingkah laku yang terdapat pada masyarakat. Penelitian ini ditinjau dari pengalaman dan pengetahuan masyarakat dalam melakukan tingkah laku yang berkaitan dengan gigi. Hal ini juga menjadi titik awal mengenai pemberian makna tersendiri bagi masyarakat mengenai kondisi gigi serta kaitannya dengan tingkah laku keputusan dalam pengobatan sakit gigi.

\section{Metode Penelitian}

Metode penelitian yang digunakan dalam penelitian ini adalah metode penelitian kualitatif dengan menggunakan pendekatan etnografi. Teknik pengumpulan data dalam penelitian ini adalah observasi dan wawancara. Observasi yang dilakukan dalam penelitian ini adalah mengamati aktifitas subyek yang diamati, lingkungan sekitar, emosi yang ditunjukkan oleh subyek penelitian, peristiwa-peristiwa penting yang memiliki hubungan dengan topik penelitian ini, serta pengamatan terhadap artefakartefak atau benda-benda yang berhubungan dengan topik penelitian ini. Wawancara yang dilakukan dalam penelitian ini adalah dengan cara melakukan percakapan tak berencana namun tetap menggunakan pedoman pertanyaan wawancara dan percakapan sambil lalu. 
Penelitian ini dilaksanakan di desa pesisir, yaitu Dusun Tawang Kulon, Desa Sidomulyo, Kecamatan Ngadirojo, Kabupaten Pacitan. Pemilihan informan dalam penelitian ini adalah masyarakat nelayan Dusun Tawang Kulon, Desa Sidomulyo, Kecamatan Ngadirojo, Kabupaten Pacitan. Pemilihan informan kunci difokuskan pada masyarakat dengan umur antara 30-90 tahun yang memiliki pengalaman terhadap kondisi gigi. Pemilihan informan ini berdasarkan beberapa alasan. Pertama, pada umur 30-90 tahun penyakit gigi pada manusia mulai terlihat jelas. Seperti gigi yang berubah warna, gigi berlubang, gigi tanggal dan lain sebagainya. Kedua, pemilihan informan dengan kisaran umur tersebut memiliki kaitan dengan pertanyaan penelitian mengenai makna atau konsep sakit gigi serta pengambilan keputusan dalam pengobatan sakit gigi. Selain itu informan yang dipilih juga orang yang memahami kebudayaan yang melingkupinya serta aspek-aspek kehidupannya. Terdapat 19 informan dalam penelitian ini, yang terdiri dari empat informan berasal dari ahli kesehatan setempat dan 15 informan berasal dari warga Dusun Tawang Kulon, Desa Sidomulyo.

Teknik analisis data yang digunakan adalah analisis data kualitatif. Analisis data kualitatif dilakukan secara bertahap atau biasa disebut analisis data bertingkat. Pertama adalah proses pengumpulan data yang sekaligus juga melakukan analisis data. Kedua dalam proses analisis data adalah reduksi dan interpretasi data. Ketiga adalah pemberian kode (coding) pada data dalam berbagai tema dan kategori. Terakhir adalah meramu data-data yang telah direduksi, telah dipresentasikan dan telah dikode dengan teori yang digunakan.

\section{Hasil Penelitian dan Pembahasan}

Pada penelitian ini ditemukan tingkah laku-tingkah laku yang berkaitan dengan gigi pada masyarakat Dusun Tawang Kulon, Desa Sidomulyo, Kecamatan Ngadirojo, Kabupaten Pacitan. Pertama tingkah laku masyarakat Dusun Tawang Kulon yang berkaitan dengan makanan adalah pembuatan makanan pokok pengganti nasi. Makanan pokok pengganti nasi masyarakat Dusun Tawang Kulon adalah tiwul. Tiwul adalah makanan pokok yang terbuat dari singkong, lebih tepatnya adalah tepung singkong yang disebut gaplek. Secara singkat tepung singkong setelah dipanen akan dikupas dan dikeringkan. Setelah kering menyerupai kayu singkong dicuci dan ditumbuh dengan $a l u$, alat penumbuk yang terbuat dari kayu. Hasil yang diperoleh adalah tepung singkong dengan tekstur sedikit kasar dan berwarna putih kusam yang disebut gaplek. Selain pembuatan gaplek, masyarakat sekitar juga menggunakan cobek yang terbuat dari batu dan tanah liat dalam proses penghalusan bumbu-bumbu masakan, seperti bumbu pecel, sambal dan lain sebagainya. Tingkah laku ini juga digambarkan Scott pada perbedaan bahan makanan serta cara pengolahannya pada masyarakat meramu dan masyarakat pertanian (Scott 1997).

Scott (1997) mengatakan bahwa segala hal yang berkaitan dengan makanan mempengaruhi kondisi gigi seperti erosi dan abrasi. Hal ini juga dimungkinkan terjadi pada masyarakat Dusun Tawang Kulon. Erosi terjadi akibat tekstur dari makanan seperti tiwul yang tidak lembut layaknya nasi, melainkan sedikit keras dan bertekstur kasar. Abrasi juga terjadi akibat masuknya materi-materi yang tanpa sengaja tercampur dalam proses pembuatan makanan. Tiwul dan makanan yang dihaluskan banyak diproses dengan alat tradisional seperti alu yang terbuat dari kayu dan cobek yang terbuat dari tanah liat dan batu. Bahan-bahan pembuatan alat tersebut dapat dengan sengaja ikut terkelupas dan bercampur dengan makanan. Terkelupasnya alat tersebut dikarenakan intensitas penggunaan yang tinggi. Penggunaan alat tumbuk tanpa pencucian terlebih dahulu juga memungkinkan bahan-bahan makanan yang dihaluskan terlebih dahulu dapat tercampur dalam bahan-bahan makanan yang akan dihaluskan selanjutnya.

Kedua, tingkah laku menggunakan gigi sebagai alat tidak banyak terjadi pada masyarakat dewasa Dusun Tawang Kulon. Tingkah laku ini banyak dilakukan oleh anak-anak dalam kegiatan menyobek kertas, dan membuka wadah plastik. Tingkah laku ini tidak menutup kemungkinan juga di lakukan oleh orang dewasa. Namun tingkah laku ini tidak dilakukan secara berulang-ulang dengan intensitas yang tinggi, melainkan hanya dilakukan sewaktu waktu jika mereka tidak menemukan pisau atau 
gunting, sehingga tingkah laku ini tidak menjadi suatu kebiasaan yang mampu menimbulkan tanda pada gigi.

Ketiga, tingkah laku manusia yang berhubungan dengan modifikasi budaya yang tidak disengaja pada masyarakat Dusun Tawang Kulon adalah penggunaan tusuk gigi. Tusuk gigi yang sering digunakan adalah lidi. Lidi terbuat dari tulang daun kelapa yang merupakan bahan utama pembuat sapu lidi. Lidi mudah ditemukan disetiap rumah tangga, bahkan setiap rumah tangga memiliki lebih dari 2 buah. Masyarakat juga mengenal tusuk gigi yang diproduksi oleh pabrik. Masyarakat menggunakan tusuk gigi di setiap mereka telah makan. Penggunaan tusuk gigi lebih mudah dilakukan untuk menggambil sisa-sisa makanan pada sela-sela gigi daripada menggunakan sikat gigi setelah makan. Kondisi gigi yang terjadi akibat kebiasaan penggunaan tusuk gigi adalah guratan-guratan pada mahkota gigi. Bahkan juga dapat memperparah karies pada gigi. Terlebih lagi jika tusuk gigi yang digunakan tidak terkontrol kebersihannya, seperti penggunaan lidi. Tingkah laku ini juga digambarkan Scott (1997) pada kebiasaan masyarakat sebelum masa modern dalam penggunaan tusuk gigi. Bahan yang digunakan dahulu adalah kayu, tulang atau bahkan helai dari rumput (Turner 1988, Brown and Molnar 1990, Alt and Kockapan 1993, Willey and Hofman 1994 dalam Alt \& Pichler 1998:404). Tingkah laku ini berpengaruh terhadap kondisi gigi, seperti terdapatnya guratan-guratan atau alur di celah-celah mahkota gigi pada kebiasaan menggunakan tusuk gigi (Scott 1997).

Keempat, tingkah laku yang berhubungan dengan modifikasi budaya yang disengaja pada masyarakat Dusun Tawang Kulon adalah kikir gigi atau mereka menyebutnya pangur dan mengunyah sirih pinang atau mereka menyebutnya nginang. Kedua tingkah laku tersebut banyak dilakukan oleh para lansia perempuan. Pangur gigi merupakan pengalaman masa remaja lansia perempuan di Dususn Tawang Kulon. Pangur gigi adalah proses pengikiran 2 atau lebih gigi pada rahang atas, terlebih lagi pada gigi seri. Hal ini dilakukan secara turun temurun tanpa sebuah upacara besar dan dilakukan sebelum masa haid pertama datang. Secara berangsur-angsur tingkah laku ini mulai ditinggalkan dan tidak dilakukan kembali. Alasan utama tingkah laku ini ditinggalkan adalah rasa sakit yang ditimbulkan setelah pangur gigi. Pangur gigi mengakibatkan gigi depan rahang atas terlihat rata dan tipis pada gigi bagian permukaan kunyah.

Mengunyah sirih pinang hingga saat ini masih tetap dilakukan pada sebagian lansia perempuan. Bahan-bahan yang digunakan terdiri dari gambir, njet atau kapur putih, suruh atau daun sirih dan tembakau. Bahan-bahan tersebut dapat diperoleh dengan mudah di toko-toko terdekat, bahkan sebagian bahan dapat ditemukan di pekarangan rumah. Kebiasaan nginang dilakukan para lansia di saat mereka telah menyelesaikan aktifitas makan baik pagi, siang maupun malam hari. Para lansia juga menghabiskan waktu luang dengan nginang disela-sela berbincang dengan tetangga, seperti pada sore hari. Setelah nginang para lansia memiliki kebiasaan untuk berkumur-kumur. Hal ini dilakukan guna menghilangkan sisa-sisa bahan-bahan nginang yang tertinggal di mulut. Lansia yang memiliki kebiasaan tersebut percaya bahwa nginang dapat memperkuat gigi serta tidak mudah menderita sakit gigi. Kondisi gigi lansia yang memiliki aktifitas mengunyah sirih pinang adalah memiliki gigi berwarna merah pekat hingga hitam, bibir dan gusi berwarna merah serta jumlah gigi yang tidak utuh kembali. Dalam tingkah laku yang berhubungan dengan budaya disengaja, Scott juga menjelaskan bahwa kegiatan tersebut terjadi dalam ritus peralihan, seperti ritus peralihan dari remaja menuju dewasa (Scott 1997:188). Terdapat beberapa tempat dengan kegiatan mutilasi gigi sering dilakukan, yaitu Afrika, Amerika Tengah dan Amerika Selatan, Philipina dan Asia Tenggara (Gould 1984, Fastlicht 1976, Galang 1941 dalam Alt \& Pichler 1998:406).

Penemuan di lapangan mengenai tiga tingkah laku masyarakat yang berkaitan dengan gigi menghasilkan pemaknaan yang masyarakat yakini. Masyarakat menyakini bahwa ketiga tingkah laku tersebut merupakan tingkah laku yang tidak membahaya gigi bahkan tidak akan berakibat pada kondisi gigi yang sakit. Melainkan, masyarakat berpendapat bahwa ketiga tingkah laku tersebut sangat membantu mereka dalam permasalahan yang berkaitan dengan gigi. Alat penghalus digunakan untuk menghaluskan makanan yang sulit dihaluskan oleh gigi. Alat tusuk gigi digunakan untuk mengambil sisa-sisa makanan yang berada pada sela-sela gigi. Kebiasaan mengunyah sirih pinang dipercayai dapat memperkuat gigi serta terhindar dari segala macam penyakit gigi. 
Jika dilihat secara mendetail ketiga tingkah laku di atas memiliki pola hubungan dengan kondisi gigi yang sakit. Pertama, pada tingkah laku yang berhubungan dengan makanan memperlihatkan bahwa tingkah laku tersebut akan menimbulkan erosi dan abrasi pada gigi. Erosi dan abrasi pada gigi, khususnya pada gigi bagian occlusal gigi molar dapat menjadi sarang bagi kuman atau bakteri yang tidak hilang dalam proses pembersihan gigi. Kuman atau bakteri tersebut akan menggerogoti mahkota gigi hingga munculnya penyakit, seperti caries. Kuman atau bakteri semakin mudah berkembang jika makanan yang dikonsumsi banyak mengandung gula dan kurangnya proses membersihkan gigi.

Kedua, pola hubungan tingkah laku dengan penyakit gigi juga terlihat dalam penggunaan tusuk gigi. Pada aktifitas penggunaan tusuk gigi, masyarakat Dusun Tawang Kulon banyak menggunakan lidi dari sapu lidi sebagai alat tusuk gigi. Sapu lidi dalam kegiatan sehari-hari merupakan alat pembersih rumah tangga, di mana keberadaan kuman atau bakteri terdapat pada sapu tersebut. Hingga pada akhirnya seorang menggunakan ujung dari lidi sebagai alat tusuk gigi. Terjadilah perpindahan kuman atau bakteri ke dalam mulut. Kuman atau bakteri yang menempel pada gigi tersebut merupakan cikal bakal dari beberapa penyakit pada gigi, seperti caries. Bentuk tusuk gigi dengan ujung runcing bermanfaat untuk mengambil sisa-sisa makanan pada lubang-lubang di mahkota gigi. Lubang-lubang kecil tersebut merupakan jenis penyakit pada gigi, yaitu caries. Penggunaan tusuk gigi akan memperburuk lubang menjadi lebih lebar. Terlebih lagi jika alat yang digunakan tidak diketahui kebersihannya, maka memperburuk kondisi gigi.

Ketiga, aktifitas nginang bagi lansia juga memiliki pola hubungan dengan penyakit pada gigi. Seperti yang telah disampaikan di atas, para lansia mempercayai bahwa dengan nginang gigi akan kuat dan terhindar dari penyakit gigi, namun banyak dari lansia tersebut memiliki gigi yang sudah tidak utuh kembali. Gigi yang tidak utuh tersebut merupakan tanda keberadaan penyakit pada gigi, seperti periodontal disease dan caries. Keadaan tersebut dapat terjadi akibat perilaku kebersihan setelah melakukan nginang tidak terjaga. Bahkan beberapa bahan-bahan nginang yang digunakan memiliki zat yang dapat mengubah kondisi gigi.

\section{Simpulan}

Terdapat tiga tingkah laku yang berkaitan dengan kondisi gigi pada masyaraat Dusun Tawang Kulon. Ketiga tingkah laku tersebut adalah, pertama tingkah laku manusia yang berhubungan dengan makanan, kedua tingkah laku manusia yang berhubungan dengan modifikasi yang tidak disengaja, dan ketiga adalah tingkah laku manusia yang berhubungan dengan modifikasi yang disengaja. Tingkah laku yang berhubungan dengan makanan dalam masyarakat Dusun Tawang Kulon dicontohkan dalam proses pembuatan bahan makanan seperti pembuatan tepung gaplek dan pembuatan bumbu-bumbu masakan. Tingkah laku yang berhubungan dengan modifikasi yang tidak disengaja dicontohkan dengan penggunaan tusuk gigi. Tingkah laku yang berhubungan dengan modifikasi yang disengaja dicontohkan dengan tingkah laku nginang dan melakukan pangur gigi bagi lansia perempuan.

Bagi masyarakat Dusun Tawang Kulon ketiga tingkah laku di atas tidak berpengaruh dengan kondisi gigi yang sakit. Bahkan masyarakat menganggap bahwa ketiga tingkah laku di atas merupakan tingkah laku yang mempermudah mereka dalam melakukan kegiatan yang berhubungan dengan gigi. Namun jika dirunut secara tepat, ketiga tingkah laku tersebut memberikan pengaruh pada kondisi gigi yang sakit.

\section{Daftar Pustaka}

Alt KW, \& Pichler SL (1998) Artificial Modifications on Human Teeth. In K. W. Alt, F. W. Rosing, \& M. Teschler-nicola (ed). Dental Anthropology: Fundamental, Limits, and Prospects (pp. 387415). New York: Springer Wien New York.

Artaria MD (2009) Antropologi dental. Yogyakarta: Graha Ilmu. 
Geertz H (1981) Aneka budaya dan komunitas di Indonesia. Jakarta: Yayasan Ilmu Ilmu Sosial \& FIS-UI.

Iptika A (2014) Keterkaitan kebiasaan dan kepercayaan mengunyah sirih Pinang dengan kesehatan gigi. Jurnal Masyarakat, Kebudayaan dan Politik, 3:64-69.

Koesbardiati T (2014) Rekonstruksi alam dan kehidupan berdasarkan rangka manusia. In Sidang Univeristas Airlangga dalam Rangka Dies Natalis ke 60 Universitas Airlangga. Surabaya: Universitas Airlangga.

Larsen CS (2008) Our origins: Discovering physical anthropology. USA: W.W. Norton \& Company, Inc.

Prossinger H \& Willms C (1998) Diet and Nutrition in Prehistoric Central Europe. In K. W. Alt, FW Rosing, \& M Teschler-nicola (ed). Dental Anthropology: Fundamental, Limits, and Prospects. New York: Springer Wien New York. 315-336.

Scott GR (1997) Dental anthropology. In Encyclopedia of Human Biology, Second Edition Vol. 3. Academic Press. 175-190.

Trikarjana P (2005) Kontroversi penyakit karies gigi dan distribusi tablet fluor di Kota Palembang. Jurnal Kedokteran dan Kesehatan Universitas Sriwijaya, 37(3), 1067-1072. 